\title{
THE DUE DILIGENCE REQUIREMENT FOR PLAINTIFFS UNDER RULE 10b-5
}

Recent years have seen an extraordinary growth in the reach of rule 10b-5. ${ }^{1}$ Further expansion in the definition of a security to reach a wide variety of transactions, ${ }^{2}$ abohtion or relaxation of the purchaser-seller standing rule, ${ }^{3}$ erosion of the scienter standard, ${ }^{4}$ and elimination of the privity requirement $t^{5}$ have all served to increase the likeh-

THE FOLLOWING CITATIONS WILL BE USED IN THIS NOTE:

A. BRomberg, SECURITIES LAW: FraUd-SEC RULE 10b-5 (1973) [hereinafter cited as A. BROMBERG];

L. Loss, Securities Regulation (2d ed. 1961) [hereinafter cited as L. Loss].

1. Securities and Exchange Commission Rule 10b-5,17 C.F.R. $\S 240.10 b-5$ (1974), provides:

It shall be unlawful for any person, directly or indirectly, by the use of any means or instrumentality of intcrstate commerce, or of the mails or of any facility of any national securities exchange,

(a) To employ any device, scheine, or artifice to defraud,

(b) To make any untrue statement of a material fact or to omit to state a material fact necessary in order to make the statements made, in the light of the circumstances under which they were made, not misleading, or

(c) To engage in any act, practice, or course of business which operates or would operate as a fraud or deceit upon any person, in counection with the purchase or sale of any security.

Rule 10b-5 was promulgated pursuant to sectiou 10(b) of the Securities Exchange Act, 15 U.S.C. $\S 78 j(b)(1970)$.

2. See, e.g., Tcherepnin v. Knight, 389 U.S. 332 (1967) (deposit in savings and loan association); Movielab, Inc. v. Berkey Photo, Inc., 452 F.2d 662 (2d Cir. 1971) (promissory note); Lehigh Valley Trust Co. v. Central Nat'l Bank, 409 F.2d 989 (5th Cir. 1969) (sale of a participation in a loan).

3. See, e.g., Eason v. General Motors Acceptauce Corp., 490 F.2d 654 (7th Cir. 1973), cert. denied, 416 U.S. 960 (1974) (Seventh Circuit rejects purchaser-seller rule); Vincent v. Moench, 473 F.2d 430 (10th Cir. 1973) (plaintiff seeking injunction need not show he was purchaser or seller of securities); Rekant v. Desser, 425 F.2d 872 (5th Cir. 1970) (in derivative suit, standing rule is met where the corporation on whose behalf suit is brought bought or sold securities); A.T. Brod \& Co. v. Perlow, 375 F.2d 393 (2d Cir. 1967) (seller in aborted transaction has standing where defendant breached agreement to buy the securities); Vine v. Beneficial Fin. Co., 374 F.2d 627 (2d Cir.), cert. denied, 389 U.S. 970 (1967) (shareholder in short form merger is "forced seller" with standing to sue).

4. Compare Smallwood v. Pearl Brewing Co., 489 F.2d 579, 606 (5th Cir. 1974); Cohen v. Franchard Corp., 478 F.2d 115, 122-23 (2d Cir. 1973) (scienter is necessary element) with Myzel v. Fields, 386 F.2d 718, 734-35 (8th Cir. 1967), cert. denied, 390 U.S. 951 (1968); Stevens v. Vowell, 343 F.2d 374, 379-80 (10th Cir. 1965); Ellis v. Carter, 291 F.2d 270, 274 (9th Cir. 1961) (defendant's negligence suffices); cf. SEC v. Texas Gulf Sulphur Co., 401 F.2d 833, 854-55 (2d Cir. 1968), cert. denied, 394 U.S. 976 (1969) (negligence suffices in SEC enforcement proceeding).

5. See, e.g., Mitchell v. Texas Gulf Sulphur Co., 446 F.2d 90, 101 (10th Cir. 1971); Heit v. Weitzen, 402 F.2d 909, 913 (2d Cir. 1968); Texas Continental Life Ins. Co. v. Dunne, 307 F.2d 242, 249 (6th Cir. 1962). 
hood of substantial recoveries by dissatisfied investors. ${ }^{\circ}$. As a result, the number of, 10b-5 suits has skyrocketed. Increasingly, however, the courts have begun to limit the reach of rule $10 \mathrm{~b}-5$ by setting standards of conduct for plaintiffs to meet. ${ }^{8}$ In a few cases suit has been barred through application of in pari delicto principles. ${ }^{9} \mathrm{~A}$ far more common rationale is to deny recovery to plaintiffs who cannot satisfy a judicially imposed "due diligence" burden. If the plaintiff alleges a material misrepresentation or omission, the- due diligence burden requires him to search out some facts concerning the advisability of a purchase or sale of securities; he must also use common sense in inter-

6. For a specific discussion of how the elimination of the purchaser-seller standing rule affects potential damages see Note, Rule 10b-5: The Rejection of the Birnbaum Doctrine by Eason v. General Motors Acceptance Corp. and the Need for a New Limitation on Damages, 1974 Duke L.J. 610.

7. See 1 A. Bromberg $§ 2.5(6)$ reporting that " $10 \mathrm{~b}-5$ is generating almost as much litigation as all the other general antifraud provisions together, and several times as much as the express liabilities." It has also been observed that "an extensive judicial gloss has encrusted" rule 10b-5 "with the result that "A startling variety of everyday transactions have turned out to 'be "firaudulent" under SEC Rule 10b-5.' " Rochez Bros., Inc. v. Rhoades, 353 F. Supp. 795, 797 (W.D. Pa. 1973) citing 1 A. BROMBERG $§ 1.1$.

8. For a general discussion of the ways in which $10 \mathrm{~b}-5$ has been contracted, see Bromberg, Are There Limits to Rule 10b-5?, 29 Buss. LAw. 167 (Special Issue, March 1974) concluding that "Five years ago, we might have said that 10b-5-like the universe, as some scientists conceive it-has limits, but they are expanding so fast, that we never reach them. In part, this is still true, but there are now a few limits . . . which seem relatively fixed and firm." Id. at 177.

9. See James v. DuBreuil, 500 F.2d 155, 159-60 (5th Cir. 1974); Kuehnert v. Texstar Corp., 412 F.2d 700, 704 (5th Cir. 1969); Wohl v. Blair \& Co., 50 F.R.D. 89, 93 (S.D.N.Y. 1970).

In pari delicto is used to bar recovery by a plaintiff who has knowingly participated in the defendant's wrongdoing. The doctrine usually arises in $10 \mathrm{~b}-5$ suits where a defendant gives the plaintiff a false inside tip which the plaintiff accepts, acts upon, and then litigates when he discovers the information is false. Since the plaintiff has knowingly used alleged "inside" information, the above-cited courts have denied recovery. But see Nathanson v. Weis, Voisin, Cannon, Inc., 325 F. Supp. 50 (S.D.N.Y. 1971) (defense of in pari delicto must yield to policy of enforcing antifraud provisions); cf. Wolf v. Frank, 477 F.2d 467 (5th Cir. 1973) (court declines to apply in pari delicto defense to suit to enforce the registration requirements of the Securities Act). Authority for declining to apply in pari delicto stems from the Supreme Court's holding in Perma Life Mufflers, Inc. v. International Parts Corp., 392 U.S. 134 (1968), where the defense was not permitted in a suit alleging violations of the federal antitrust laws. In any event, the doctrine is of marginal utility in $10 \mathrm{~b}-5$ suits because the factual situation to which the doctrine would apply rarely arises.

See generally Bell, How to Bar an Uninnocent Investor-The Validity of Common Law Defenses to Private Actions Under the Securities Exchange Act of 1934, 23 U. FLA. L. Rev. 1 (1970); Godfrey, Plaintiff's Conduct as a Bar to Recovery Under the Securities Acts: In Pari Delicto, 48 TEx. L. Rev. 181 (1969); Comment, Demise of In Pari Delicto in Private Actions Pursuant to Regulatory Schemes, 60 CAL. L. REv. 527, 579-. 95 (1972); Comment, Rule 10b-5: The In Pari Delicto and Unclean Hands Defenses, 58 CAL. L. Rev. 1149 (1970); 1969 Duke L, J; 832. 
preting those facts given to him. If the plaintiff alleges that he was the victim of a fraudulent device or practice, he is required to show that the fraud was perpetrated despite his own reasonable conduct. Likewise, a plaintiff may not invoke the equitable tolling doctrine to prevent the statute of limitations from barring his action if he failed to bring it within a reasonable time after discovery of the fraud or misrepresentation or a reasonable time after the plaintiff should have discovered the $10 \mathrm{~b}-5$ violation.

The recent plethora of case law has inade it possible to formulate general standards for determining whether a plaintiff has in fact satisfied his due diligence burden. Such a formulation should help all parties engaged in securities transactions by setting forth the specific elements of this emerging "code of conduct" for mvestors. To this end, it will first be shown that the imposition of a due diligence requirement is theoretically sound. ${ }^{10}$ The second section of this Note will then examine in detail the standards which investors must meet. ${ }^{11}$

\section{Theoretical ConstDerations Behind The Due Diligence Burden}

Before inquiring into the exact scope of a plaintiff's due diligence burden, it is necessary to demonstrate that an investor's constructive knowledge ${ }^{12}$ justifies imposing such a burden on $10 \mathrm{~b}-5$ plaintiffs. Although the courts generally agree that this requirement is proper, their reasoning has varied widely. This section of the Note will describe the numerous judicial rationales employed, identify the analytical problems posed by many of them and suggest the appropriate theoretical approach.

\section{Constructive Knowledge of a Fraudulent Device or Practice}

Often courts faced with non-diligent plaintiffs in fraudulent scheine or device cases have employed such concepts as waiver, ${ }^{13}$ laches, ${ }^{14}$ and estoppe ${ }^{15}$ in denyimg recovery. ${ }^{16}$ These doctrines, how-

10. See notes $12-43$ infra and accompanying text.

11. See notes 44-134 infra and accompanying text. See also A. JACOBS, The IMPACT OF RULE 10b-5 § 64.01[b][ii] at 3-172-3-174 (1st ed. 1974).

12. Constructive knowledge is defined as that which a person should know as opposed to what he does know. See 2 A. Bromberg $\$ 8.4$ (531).

13. See, e.g., Ocrant v. Dean Witter \& Co., 502 F.2d 854 (10th Cir. 1974); Hecht v. Harris, Upham \& Co., 283 F. Supp. 417 (N.D. Cal. 1968), modified, 430 F.2d 1202 (9th Cir. 1970); cf. Fey v. Walston \& Co., 493 F.2d 1036 (7th Cir. 1974) (no waiver found).

14. See, e.g., Ocrant v. Dean Witter \& Co., 502 F.2d 854 (10th Cir. 1974); Hecht 
ever, are actually of very limited utility, both because of the narrow circumstances to which they apply and because of the substantial theoretical problems concerning their applicability in $10 \mathrm{~b}-5$ suits. Waiver, at least as construed by the Ninth Circuit, is limited to cases where the plaintiff had actual, as opposed to inerely constructive, knowledge of the right in question. ${ }^{17}$ Problems are also raised by section 29(a) of the Securities Exchange Act which voids waivers of the rights granted by the Act. ${ }^{18}$ Laches and equitable estoppel, on the other hand, require that the defendant have suffered some injury or prejudice. ${ }^{10}$ Quite often, however, such detriment or injury is difficult to show. ${ }^{20}$ In addition, it is questionable whether laches can bar a

v. Harris, Upham \& Co., 283 F. Supp. 417 (N.D. Cal. 1968), modified, 430 F.2d 1202 (9th Cir. 1970).

15. See, e.g., Ocrant v. Dean Witter \& Co., 502 F.2d 854 (10th Cir. 1974); Landry v. Hemphill, Noyes \&_. Co., 473 F.2d 365 (1st Cir.), cert. denied, 414 U.S. 1002 (1973); Hecht v. Harris, Upham \& Co., 283 F. Supp. 417 (N.D. Cal. 1968), modified, 430 F.2d 1202 (9th Cir. 1970); cf. Fey v. Walston \& Co., 493 F.2d 1036 (7th Cir. 1974) (no estoppel found).

16. See generally Note, Applicability of Waiver, Estoppel, and Laches Defenses to Private Suits Under the Securities Act and S.E.C. Rule 10b-5: Deterrence and Equity in Balance, 73 YALE L.J. 1477 (1964).

17. See Royal Air Properties, Inc. v. Smith, 333 F.2d 568 (9th Cir. 1964).

18. Section 29(a) of the Securities Exchange Act, 15 U.S.C. \& 78cc (1970) provides:

Any condition, stipulation, or provision binding any person to waive comphance with any provision of: this chapter or of any rule or regulation thereunder, or of any rule of an exchange required thereby shall be void.

19. The Ninth Circuit, in Hecht v. Harris, Upham \& Co., 430 F.2d 1202 (9th Cir. 1970), has defined both estoppel and laches in the context of a 10b-5 suit:

The requirements of estoppel are set out in Hampton v. Paramount Pictures, 9 Cir., 279 F.2d 100, 104 (1960):

"Four elements must be present to establish the defense of estoppel: (1) the party to be estopped must know the facts; (2) he must intend that his conduct shall be acted on or inust so act that the party asserting the estoppel has a right to beheve it is so intended; (3) the latter must be ignorant of the true facts; and (4) he must rely on the former's conduct to his injury" (citations omitted).

To invoke laches as a defense there must be (1) a lack of diligence by the party against whom the defense is asserted, and (2) prejudice to the party asserting the defense. 430 F.2d at 1208.

20. In Royal Properties, Inc. v. Sinith, 333 F.2d 568 (9th Cir. 1964), the defendant corporation argued that it was building certain apartments at the time of the misrepresentatiou and could have saved money by economizing on certain items, but did not do so because of its reliance on the plaintiff's silence. The court rejected this argument noting that economizing on the apartments would as a consequence have lessened the sales price of the property. Thus any savings would have been offset by a lower price and would not have truly benefited the corporation.

For a case where estoppel was more appropriately raised, see Hochfelder v. Ernst \& Ernst, 503. F.2d 1100 (7th Cir. 1974), where it was alleged that the defendant accounting firm negligently andited a wrongdoing brokerage house, thereby aiding and abetting the fraudulent scheme of the brokerage firm's president involving some fake escrow accounts. As a defense, Ernst \& Ernst argued that it had sent requests for 
plaintiff seeking a legal remedy. ${ }^{21}$

An alternative rationale for barring suit by plaintiffs with constructive knowledge of a fraudulent scheme is to read imto the first and third clauses of rule 10b-5 the common law fraud requirement of justifiable reliance. ${ }^{22}$ This approach is also suspect, however, because it presumes an erroneous equivalence between the fraudulent scheme or device clauses of rule $10 \mathrm{~b}-5$ and common law fraud actions. ${ }^{23}$

\section{Constructive Knowledge of a Material Misrepresentation or Omission}

Courts have offered several explanations why the plaintiff's constructive knowledge of an alleged material misrepresentation or omission should bar a 10b-5 cause of action. Waiver, laches and estoppel have been suggested as rationales for denying recovery in these cases, despite theoretical difficulties similar to those described above. ${ }^{24} \mathrm{Sev}-$ eral courts and commentators have looked at the matter in terms of the defendant's scienter or negligence, reasoning that where the plaintiff had easy access to the omitted or misrepresented information, the defendant was under no duty to disclose it. ${ }^{25}$ The scienter-negligence

written confirmations to all of the brokerage firm's customers as to their accounts. None of the plaintiffs bothered to report their escrow accounts. Ernst \& Ernst thus contended that it was misled to its detriment by the plaintiffs' non-diligeut conduct. The Seventh Circuit sent the case to trial to resolve whether the plaintiffs knew or should have known they were to report the escrow accounts.

21. See $3 \mathrm{~L}$. Loss 1777 . Professor Loss points out that while the equitable tolling doctrime applies to both actions at law and in equity, the tolling doctrine is meant to protect the reasonably diligent plaintiff. It does not, therefore, necessarily follow that the plaintiff who seeks a legal remedy on a federal cause of action should be barred by laches short of the expiration of the statutory period for bringing suit.

22. See W. PROSSER, HANDBOOK OF THE LAW OF TORTS $\$ 108$ (4th ed. 1971).

23. Rule 15c1-7(a), 17 C.F.R. \& 240.15c1-7 (1974), for example, specifically defines "churning" as a fraudulent device within the meaning of rule 10b-5. Yet it has beeu held that in a cluming case proof of specific or invidious intent to defraud is not required, although such an intent would be necessary under common law fraud. Moreover, while a complainant alleging common law fraud has the burden of proving fraud by clear, cogent and convincing evidence, a complainant alleging fraudulent chuming activity inust merely meet a preponderauce of the evidence staudard. See Dzenits v. Merrill Lyncl, Pierce, Fenner \& Smith, Inc., 494 F.2d 168, 171 n.2 (10th Cir. 1974). Cf. SEC v. Capital Gains Research Bureau, 375 U.S. 180 (1963) (no actual intent to injure necessary in suit under similar clauses contained in Investment Advisers Act). See generally 1 A. BROMBERG $\$ 2.7$, comparing rule 10b-5 with common law fraud.

24. See notes 13-21 supra and accompanying text. For a discussion of waiver, laches and estoppel in the context of a material misrepresentation and omission case, see Royal Air Properties, Inc. v. Smith, 333 F.2d 568 (9th Cir. 1964).

25. See, e.g., White v. Abrams, 495 F.2d 724 (9th Cir. 1974) (defendant's duty of disclosure depends, inter alia, on defendant's access to the infornation as coinpared with plaintiff's access); Arber v. Essex Wire Corp., 490 F.2d 414 (6th Cir.), cert. denied, 419 U.S. 830 (1974) (defendant has no duty to disclose routine corporate data easily 
requirement is itself a "creature of judicial inference;"26 the omission or misrepresentation clause of rule 10b-5 makes no mention of a defendant's intent or standard of care. ${ }^{27}$ The usual justification for the inference is that since a private cause of action under $10 \mathrm{~b}-5$ is judicially implied, courts, in accord with their notions of legislative intent, may read into the action elements not expressly contained in the language of the rule. ${ }^{28}$ The difficulty with this approach results from confusion of two different "scienters." "Scienter" as an element under rule $10 \mathrm{~b}-5$ means the lack of diligence, constructive fraud, or unreasonable or negligent conduct of the defendant. ${ }^{20}$ Nothing in the traditional notion of scienter justifies an additional examination of the plaintiff's scienter and then balancing the two. Thus, to say that a defendant lacks scienter where the plaintiff has it (as evidenced by the plaintiff's lack of diligence in failing to examine the easily accessible omitted or misrepresented information) is to add a very new twist to the traditional notion of scienter.

Other courts and commentators discuss the plaintiff's constructive knowledge in terms of his "reasonable rehance" on the misrepresentation or omission. ${ }^{30}$ The rehance requirement, like scienter-neghgence, also stems from judicial inference, borrowing from the common law tort of deceit, simce $10 \mathrm{~b}-5$ does not literally require a showing of rehance. ${ }^{31}$ Whatever validity this rationale may once lave

available to plaintiff); Kohler v. Kohler, 319 F.2d 634 (7th Cir. 1963) (no duty of disclosure to plaintiff with years of intimate acquaintance with corporate affairs); Harnett v. Ryan Homes, Inc., 360 F. Supp. 878 (W.D. Pa. 1973), aff'd, 496 F.2d 832 (3d Cir. 1974) (one insider cannot maintain suit against another since there is no duty to disclose information to one who reasonably should already be aware of it); Mann, Rule 10b-5, Evolution of a Continuum of Conduct to Replace the Catch Phrases of Negligence and Scienter, 45 N.Y.U.L. REv. 1206, 1215 (1970) ("the defendant will be held to a lower standard of conduct as the sophistication of the plaintiff and his ability to protect his own interests increases.").

26. Comment, Negligent Misrepresentations Under Rule 10b-5, 32 U. CH. L. Rev. 824, 827-28 n.16 (1965).

27. See note 1 supra for text of Rule 10b-5.

28. See Coininent, supra note 26.

29. See SEC v. Texas Gulf Sulphur Co., 401 F.2d 833, 855 (2d Cir. 1968), cert. denied, 394 U.S. 976 (1969).

30. Mitchell v. Texas Gulf Sulphur Co., 446 F.2d 90 (10th Cir. 1971) (seller cannot claim reliance on deceptive press release after curative release has been issued and should have been assimilated); Comment, Reliance Under Rule 10b-5: Is the "Reasonable Investor" Reasonable?, 72 Colum. L. Rev. 562 (1972). See also A. JACOBS, supra note 11, § 64.01[b][iii] (discussion of "justifiable reliance").

Some courts have held both that the defendant was under no duty of disclosure and that the plaintiff was not reasonably entitled to rely on the nondisclosure where the plaintiff did not himself reasonably investigate. See, e.g., Niedermeyer v. Niedermeyer, [1973 Transfer Binder] CCH Feb. SEC. L. ReP. If 94,123 at 94,500-01 (D. Ore. 1973).

31. 3 L. Loss 1765-66; Stoll, Reliance as an Element in 10b-5 Actions, 53 ORE. L. 
had, it has become subject to serious doubt since the Supreme Court's recent holding in Affiliated Ute Citizens v. United States ${ }^{32}$ that, at least in omission cases, positive proof of actual reliance is not a prerequisite to recovery. ${ }^{33}$ Because of Affiliated Ute, it is no longer possible to base a due diligence burden upon the necessity of reliance when the plaintiff alleges a material omission. In view of the uncertain future of the reliance requirement in other 10b-5 actions, it cannot be assumed that this particular rationale for imposing due diligence standards will survive in misrepresentation cases either. ${ }^{34}$

Perliaps as a consequence of Affiliated Ute, some courts have suggested that a plaintiff's knowledge bears on the materiality requirement of a $10 \mathrm{~b}-5$ suit which alleges a material omission or misrepresentation. ${ }^{35}$ Materiality is generally defimed as whether a reasonable investor might consider the fact important to his investment decision. $^{36}$ The courts which view a plaintiff's knowledge in terms of materiality then read into this definition of materiality the assumption that investors would vary as to their diligence; certain investors, in order to be reasonable, would "more diligently test the rehability and completeness of representations made concerning a proposed transaction before considering them important." ${ }^{37}$ This reasoning, however, seems an unwarranted stretch of the definition of materiality and unnecessarily confuses materiality with due diligence. An investor might reasonably deem a representation of great importance were it true, yet, at the saine time, realize that the representation was so outrageous that it could not reasonably be believed. Tlius, a misrepresentation

REv. 169, 171 (1974). For some evidence that reliance is intended by the legislature to be an element, an analogy may be drawn to section 9 of the Securities Exchange Act, 15 U.S.C. $\$ 78 \mathrm{i}(1970)$, which gives a private cause of action against market manipulators. Although section 9 says nothing about reliance, a legislative report states that in such cases the burden is on the plaintiff to show that he relied on the defendant's act. See S. Rep. No. 792, 73 d Cong., 2d Sess. 13 (1934).

32. 406 U.S. 128 (1972).

33. All that is necessary is that the omission be material. See id. at 153-54.

34. For a good discussion of the status of reliance after Affiliated Ute see Note, The Reliance Requirement in Private Actions Under SEC Rule 10b-5, 88 HARv. L. Rev. 584 (1975).

35. See, e.g., Bragalini v. Biblowitz [1973-74 Transfer Binder] CCH Fed. SEc. L. REP. II 94,371, at 95,267 (S.D.N.Y. 1974) (none of the alleged omissions found material since reasonable stockholders should know of the poor financial condition of the corporation); Taylor v. Smith, Barney \& Co., 358 F. Supp. 892, 896 n.11 (D. Utah 1973) (discussions of reasonable reliance are nothing more than discussions of materiality under another name); Stoll, supra note 31, at 181.

36. See 406 U.S. at 153-54 (1972); List v. Fashion Park, Inc., 340 F.2d 457, 462 (2d Cir.), cert. denied, 382 U.S. 811 (1965); Taylor v. Smith, Barney \& Co., 358 F. Supp. 892, 895 (D. Utah 1973).

37. See, e.g., Taylor v. Smith, Barney \& Co., 358 F. Supp. 892, 895 (D. Utah 1973). 
could be material yet not actionable because the plaintiff failed in his due diligence burden. ${ }^{38}$ Moreover, tying inateriality to the plaintiff's sophistication might logically mean that more information should be disclosed to sophisticated investors than to unsophisticated ones since only the former group could appreciate disclosure of highly technical investment information.

\section{Due Diligence as a Separate Element}

In place of the welter of rationales derived from the individual elements of rule $10 \mathrm{~b}-5$, some courts have adopted the approach of treating plaintiffs' due diligence as a totally separate element of a $10 \mathrm{~b}$ 5 cause of action..$^{30}$ Because of the applicability of this rationale to all of the rule's provisions, its potential utility is evident. The approach is also theoretically impeccable. Creating a due diligence element for 10b-5 suits would not be an unwarranted judicial assumption of legislative prerogative, simce the courts have already created the elements

38. See A. JACOBS, supra note $11, \$ 64.01$ [b][iii]. The author offers as an example a representation that the company had developed a way to convert air into gold at a cost of 15 cents per pound. See id. at 3-176 n.14. The representation is material since a reasonable investor would attach great weight to it if true, yet no reasonable person would believe it.

39. See, e.g., Rochez Bros., Inc. v. Rhoades, 491 F.2d 402, 409-10 (3d Cir. 1973); Jackson v. Oppenheim, [Current Transfer Binder] CCH FED. SEc. L. REP. II 94,894 at 97,041-43 (S.D.N.Y. Nov. 21, 1974). Both cases contain a separate subheading discussing "due care."

See also Note, supra note 34, at 603-06 (1975), where the author recognizes the plaintiff's lack of due diligence as simply an affirmative defense in 10b-5 suits. The author draws an analogy to contributory negligence and reasons that, in light of the deterrent purposes of $10 \mathrm{~b}-5$, it would be anomalous to impose a stricter standard on the plaintiff to establish a claim for securities fraud than the common law imposes for negligence claims. $I d$. at 606 . However, it might also be argued that, inasmuch as a $10 \mathrm{~b}$ 5 suit is not a simple negligence action, more of a burden can fairly be put on the plaintiff. Most courts seem to consider due diligence as an element of the plaintiff's case, either by specifically denominating due diligence as an "element", or by tying due diligence to some other element such as scienter, reliance or materiality, see notes 24-38 supra and accompanying text.

This commentator also states that the due diligence defense would not apply in the open market context where the plaintiff is injured only by the fact that other investors have acted on the defendant's deception, thereby interfering with the "true" market price of the stock. $I d$. at 605 . However, it is easy to imagine situations where due diligence would be raised even in the open market context. One possible scenario: defendant falsely informs a large investor that X Co. stock is about to rise dramatically; the large investor buys, forcing the market price up. Plaintiff then hears froin a friend, an insider in X Co., that management is concerned about the peculiar rise in the market price. Despite this warning that the market price may be artificially inflated, plaintiff purchases. The deception is then discovered and the market price bottoms out. In the ensuing litigation, it would seem reasonable to allow defendant to raise plaintiff's failure to exercise due care in making his purchase. 
of reliance and scienter-negligence in $10 \mathrm{~b}-5$ suits. It has been generally accepted that these judicial creations are proper. The argument is this: Since it was the courts which originally implied a private right of action under rule $10 \mathrm{~b}-5$, they are empowered to define its elements in such a way as to effectuate legislative policy. This reasoning applies with full force to the creation of a due diligence requirement for plaintiffs. Such a requirement clearly complies with the recognized legislative policy of equalizing access to information; full disclosure is unnecessary where both plaintiff and defendant have access to all material facts. ${ }^{40}$

\section{Constructive Knowledge and the Statute of Limitations}

A due diligence requirement for plaintiffs has also appeared in the context of applying the statute of limitations. The problem arises when the statute of limitations has run, and the plaintiff seeks to escape its effect by invoking the equitable tolling doctrine. This doctrine, originally announced by the Supreme Court in Bailey $\%$. Glover, ${ }^{41}$ states that the statute of limitations will not begin to run against a party injured by fraud until the fraud is discovered, provided that his prior ignorance of the fraud did not result froin his lack of diligence. The statute will be tolled even though there are no special efforts by the party committing the fraud to conceal it from the other party. ${ }^{42}$ This doctrine applies to all federally created remedies and is thus apphicable in $10 \mathrm{~b}-5$ suits, although the actual statute of limita-

40. There is authority for the view that the purpose of rule $10 \mathrm{~b}-5$ is to assure equal access to information. See SEC v. Texas Gulf Sulphur Co., 401 F.2d 833, 848 (2d Cir. 1968), cert. denied, 394 U.S. 976 (1969):

... [T]he Rule is based in policy on the justifiable expectation of the securities marketplace that all investors trading on impersonal exchanges have relatively equal access to material information. .... The essence of the Rule is that anyone who, trading for his own account in the securities of a corporation has "access, directly or indirectly, to information intended to be available only for a corporate purpose and not for the personal benefit of anyone" nay not take "advantage of such information knowing it is unavailable to those with whom he is dealing. ..."

See also 1 A. BRomberg $\$ 3.2(300)-(400)$ (rationale of rule is equalizatiou of information). Although $10 \mathrm{~b}-5$ has been termed a full disclosure rule, disclosure is not necessarily mandated by the rule since an investor may elect to abstain from trading rather than disclose inside information.

Soine courts have gone so far to say that the rule protects only "conscientious buyers and sellers in good faith." See, e.g., City Nat'1 Bank v. Vanderboom, 422 F.2d 221, 230 n.10 (8th Cir.), cert. denied, 399 U.S. 905 (1970); Branham v. Material Systems Corp., 354 F. Supp. 1048, 1056 (S.D. Fla. 1973). A due diligence requirement would also encourage imvestors to be inore careful in securities transactions, thereby preventing frauds at the outset.

41. 88 U.S. 342 (1874).

42. Id. at 348. The rule applies to suits both in equity and at law. Id. at 349 . 
tions employed in such suits is that of the state. ${ }^{43}$

\section{Extent of the Due Diligence Burden}

Given that rule 10b-5 justifies the imposition of a burden on plaintiffs to search out certain facts relevant to the advisability of a purchase or sale of securities and to act in a reasonable manner so as to prevent the perpetration of fraudulent schemes, the exact extent of that burden reinains to be determined. Obviously a plaintiff's due diligence burden can only be determined under the peculiar circumstances of each case; that burden will grow as the plaintiff's opportunity to detect the misrepresentation or prevent the fraud increases. However, the great majority of plaintiffs will fall into one of several very broad categories, each including nueinbers similarly situated as to the types of available information. For this reason, it is possible to deseribe in general terms the standards of inquiry which will be imposed upon investors in a given class. Accordingly, this section of the Note will consider how the due diligence requirement varies according to the plaintiff's position as (1) a corporate insider; (2) an investor with special experience or expertise; or (3) an "ordinary" investor.

Insider Plaintiffs. An insider is usually thought of as an officer or director of a corporation but may actually be any person who, because of his position or intimate association with a corporation, has special knowledge of corporate financial affairs. ${ }^{44}$ The following discussion is limited to officers and directors since no cases appear to have arisen involving other types of corporate insiders. ${ }^{45}$

Soine courts have flatly asserted that one insider cannot recover from another. ${ }^{46}$ However, this statement is clearly too broad as no court has actually so held, at least in the absence of other factors. A niore reasonable view, and a more accurate statement under the existing cases, would be that an insider has a stringent but not impossible

43. See de Haas v. Empire Petroleum Co., 435 F.2d 1223, 1226 (10th Cir. 1970); Azalea Meats, Inc. v. Muscat, 386 F.2d 5, 8 (5th Cir. 1967).

44. Myzel v. Fields, 386 F.2d 718, 739 (8th Cir. 1967), cert. denied, 390 U.S. 951 (1968); Harnett v. Ryan Homes, Inc., 360 F. Supp. 878, 886 (W.D. Pa. 1973), aff'd, 496 F.2d 832 (3d Cir. 1974).

45. Presumably other insiders, such as controlling shareholders, would have a lesser due diligence burden than officers and directors. The right of a shareholder to inspect corporate records, for example, is only a qualified right while a director's inspection right is absolute. See notes 51 and 113 infra and accompanying text. Nor would a controlling shareholder necessarily be in a position to receive "office information." Cf. notes 58-60 infra and accompanying text.

46. E.g., Harnett v. Ryan Homes, Inc., 360 F. Supp. 878, 885 (W.D. Pa. 1973), aff'd, 496 F.2d 832 (3d Cir. 1974). 
duty of investigation and may still recover if the nondisclosure or misrepresentation related to something that not even an insider could [have detected], or if the defendant's fraud were not made possible by the officer's or director's lack of diligence.

Corporate Books and Records and Corporate Meetings. If an insider is an officer or director, he will be chargeable with notice of all facts which the corporate records and meetings at which he was in attendance would "fairly disclose." $4 \tau$ For example, in Jackson v. Oppenheim, ${ }^{48}$ the plaintiff, a partner in the law firm of Rogers \& Wells, purchased stock in Chelsea House Educational Communications, Inc., of which he was an officer and director. He alleged that the seller, a vice president and director of Chelsea House, failed to disclose Chelsea's financial difficulties. ${ }^{49}$ The court, however, denied recovery, finding that the plaintiff, albeit an outside director, had access to corporate books and records which would have revealed that Chelsea was at the end of its credit line and current habilities exceeded current assets by $\$ 500,000 .{ }^{50}$ This decision logically follows from the fact that state law gives directors an absolute right to inspect corporate books and records and that such directors will generally not be put to undue effort in order to exercise that right. ${ }^{51}$ Furthermore, it is reasonable to assune that anyone serving as a director should have acquired the requisite expertise to understand the records. ${ }^{52}$ However, if

47. Myzel v. Fields, 386 F.2d 718, 736 (8th Cir. 1967), cert. denied, 390 U.S. 951 (1968); Niedermeyer v. Niedermeyer [1973 Transfer Binder] CCH Fed. Szc. L. REP. If 94,123 at 94,501 (D. Ore. 1973).

48. [Current Transfer Binder] CCH FED. SEC. L. REP. If 94,894 (S.D.N.Y. Nov. 21, 1974).

49. Id. at 97,037 .

50. Id. at 97,042. For a further discussion of this case see note 60 infra.

51. See W. Cary, Cases and Materials on Corporations 1027-28 (4th ed., unabridged, 1969); 1 G. HoRNSTEIN, Corporation LAW AND PRACTTCE $\$ 421$ (1959).

It is interesting to note that in Jackson the bookkeeper of Chelsea testified she would have denied access to the corporate records to both plaintiff and defendant until the president's approval was obtained. The court did not discuss this point since there was no evidence that the plaintiff had even sought access. However, if the plaintiff could have shown that the president would, in fact, have denied access to the plaintiff but not to the defendant, then the case might have conre out differently. See note 53 infra and accompanying text.

52. In Jackson the court pointed out that the plaintiff "admittedly possessed a high degree of sophistication with regard to corporate matters as evidenced by his service as director on the boards of approximately ten companies." [Current Transfer Binder], CCH Fed. SEC. L. REP. If 94,894, at 97,042.

Even if the plaintiff does not have the expertise to thoronghly understand corporate financial records, many statutes permit the director to inspect the records through an agent or attorney. See, e.g., CAL. CoRP. CoDE $\$ 3004$ (West 1955). Many statutes also give the director the right to inake extracts. See id. 
the plaintiff director can establisl that he is a mere "dummy," is not given a responsible role, and has no easy physical access to the corporate books and records, then the plaintiff should be able to recover against an insider for misrepresentations of the corporate financial picture. ${ }^{53}$ Even though directors liave the legal right to examine corporate records, they should not be forced to sue for inspection rights merely to preserve their recovery in future lawsuits.

Insiders have also been clrarged with knowledge which sliould have been acquired at corporate meetings which they attended. In Niedermeyer $v$. Niedermeyer, ${ }^{54}$ an executive vice-president and director alleged that a purchase of company stock from his brother, the president, was caused by material misrepresentations and omissions relating to the amount of corporate assets. The overstatement of assets resulted from careless inventory counts and from the corporation's practice of pre-invoicing. ${ }^{55}$ Botli problems had been brought out at a meeting with bank officials who were worricd about credit which had been extended to the corporation. Finding that the plaintiff was present at this meeting, the court concluded that the plaintiff was put on notice that the corporate assets might not be accurately stated. ${ }^{56}$ Recovery was thus demed. A different conclusion might liave been reached if the plaintiff liad not actually been present at the bank meeting, since apparently no minutes of the meeting were kept. If the pre-invoicing and careless inventory counts had been raised at a directors' meeting, lrowever, then even an absent director would be put on notice because the minutes would be part of the corporate records to whicl he liad access. ${ }^{57}$

53. Cf. Myzel v. Fields, 386 F.2d 718, 736 n.11 (8th Cir. 1967), cert. denied, 390 U.S. 951 (1968) (dictum); Taylor v. Janigan, 212 F. Supp. 794 (D. Mass. 1962), on damages, 230 F. Supp. 858 (D. Mass. 1964), modified as to damages, 344 F.2d 787 (1st Cir.), cert. denied, 382 U.S. 879 (1965). In the latter case the court, in allowing the plaintiff to recover, may also have been influenced by the fact that even if the plaintiffs had had access to the corporate books they would not have learned the truth, since the defendant had manipulated the figures in order to show lower profits. See also Thomas v. Duralite Co., Inc., 386 F. Supp. 698 (D.N.J. 1974) (plaintiff who left the company and his position as executive vice-president three years before the sale of his stock and who thereafter no longer had access to monthly status reports is not chargeable with notice that financial condition of company had turned around).

54. [1973 Transfer Binder] CCH Feb. Sec. L. ReP. I 94,123 (D. Ore. 1973).

55. Pre-invoicing is the practice of preparing an mvoice on an order and sending it to the bank for credit before the order is actually shipped. The practice results in an increase in assets without a corresponding decrease in inventory.

56. [1973 Transfer Binder] CCH FED. SEC. L. REP. \ 94,123 at 94,497, 94,501.

57. But see Rogen v. Mlikon Corp., 361 F.2d 260 (1st Cir. 1966). Plaintiff and defendants, all M.I.T. doctoral candidates, organized a corporation for the development of aluminum products. After some technological improvements, the plaintiff wrote Rey- 
Office Information. A few courts have gone beyond the rule charging officers and directors with notice of corporate records and meetings and have charged an officer with knowledge of certain types of "office information" as well. In Harnett v. Ryan Homes, Inc., ${ }^{58}$ an executive vice-president of marketing for Ryan Homes, a land development company, alleged that he sold his stock back to the corporation because of misrepresentations and omissions by the president. One allegation was that the defendant failed to inform the plaintiff of a lucrative option which Ryan Homes had been assigned. The court found, however, that the option had been discussed at a special meeting of the board of directors almost five months before the plaintiff's stock sale. Although the court admitted that the plaintiff was not a director (and thus apparently did not attend the meeting), it deemed it improbable that the plaintiff "could have missed such knowledge." 50 This conclusion is probably correct in view of the fact that the plaintiff was a full-time officer, the option proved beneficial to the corporation and was thus newsworthy, and the information had undoubtedly been a conversation topic for almost five months. ${ }^{60}$

nolds Metal $\mathrm{Co}$., which expressed interest but deinanded a release before negotiations could proceed. Negotiations were therefore dropped. Soon afterwards, plaintiff and defendants had a falling out and plaintiff was dismissed as president and secretary, although he still remained a director. Id. at 262. About four months later the plaintiff sold his stock for what he later discovered to be an unfortunately low price. He then brought suit, alleging that the defendants had oinitted to inform hin that negotiations with Reynolds had been revived. Id. at 263. The court, however, found that the negotiations with Reynolds had been discussed at a board meeting of which the plaintiff had notice but declined to attend; in fact, the plaintiff had made absolutely no effort to find out what was going on in the corporation between the time he was dismissed as president and the time he sold his stock. Id. at 267. Nevertheless, the court sent the case to trial. The case can only be explained by noting that the plaintiff had alleged that any inquiry would be useless because the defendants would not talk with him and that, if he had attended the directors' meeting, the agenda would have been changed. Id. at 268. If a plaintiff's due diligence investigation would surely fail, then there is no reason to require it.

58. 360 F. Supp. 878 (W.D. Pa. 1973), aff'd, 496 F.2d 832 (3d Cir. 1974).

59. Id. at 887. Although the opinion is anbiguous, the court apparently did not rest its holding on the alternative rationale that the information was contained in the corporate minutes to which the plaintiff had access.

60. Id. "Office information" may also reach outside directors. In Jackson, see notes 48-53 supra and accompanying text, the plaintiff had also alleged that the defendant seller failed to disclose certain mismanagement problenns, for example, that the pub. licity department at Chelsea ran costly ads in newspapers when the books which were the subjects of the ads were not in the stores. It seems unlikely that an examination of corporate records would have revealed sucl information. The court did find, however, that the plaintiff had, shortly before the sale, met with the plaintiff at the latter's office and had at that time outlined some of his grievances against management. The court thus found that the plaintiff was put on notice of the mismanagement problems. [Current Transfer Binder] CCH FED. SEC. L. REP. If 94,894 at 97,042-43. 
Harnett can be contrasted with Rochez Bros., Inc. v. Rhoades, ${ }^{01}$ also decided by the Third Circuit. In that case the seller, a part-time vice president and director, alleged that the president of the corporation purchased the plaintiff's stock without disclosing that he had hired a finder to look for prospective purchasers and had already seriously negotiated for the possible resale of all the stock. The court allowed the plaintiff to recover, finding that none of the corporate books, records or minutes which were available to the plaintiff contained information regarding the defendant's negotiations with other purchasers. ${ }^{62}$ Further, the information was not available to the plaintiff from any other "general office" source; the defendant had imposed controls over who could open the mail and had directed his finder to remain silent when in the plaintiff's presence. ${ }^{63}$

Another decision illustrating the principle that an insider inay recover where the misrepresentations or omissions were not discoverable from either corporate records and meetings or general office sources is Myzel v. Fields, ${ }^{04}$ where the seller was a member of the board of directors and had been specially "trained in financial affairs." the actual purchaser of the plaintiff's stock. Since "labyrinthine transfers" hid the true identity of the purchaser "from even a most alert director," recovery was permitted. ${ }^{60}$

Common Sense. The decision in Harnett also illustrates that an insider must interpret those facts given to him with common sense and, perhaps, cum grano salis. Among the alleged misrepresentations in Harnett were that "Ryan Homes" would always be built in a certain

61. 491 F.2d 402 (3d Cir. 1973).

62. Id. at $409-10$.

63. Id. at 408 n.9. The opinion can be criticized, lowever, on "actual reliance" grounds. From earlier negotiations authorized by the board of directors, the plaintiff knew that the defendant liad valued a 50 percent interest in the company to a possible outside purchaser at $\$ 1.75$ million; this the plaintiff considered "ludicrously high." Id. at $410-11$.

What makes the decision even nore questionable is the way in which the court computed the plaintiff's damages. Although the defendant received an offer of approximately $\$ 2$ million for all the stock (both plaintiff and defendant had each held 50 percent) a short tinie after the plaintiff's sale, the defendant did not accept this offer. Instead, the defendant accepted an offer of $\$ 4.25$ million from a different purchaser some seven months after the plaintiff had sold out. The Third Circuit awarded the plaintiff half of the $\$ 4.25$ million minus the $\$ 598,000$ the plaintiff had received from the defendant, despite evidence that it was the defendant's sole efforts which built the company, in those seven months, into an enterprise wortli over $\$ 4$ million. Id. at 412.

64. 386 F.2d 718 (8th Cir. 1967), cert. denied, 390 U.S. 951 (1968).

65. Id. at 736 .

66. Id. at 737 . 
new development area and that the corporation was going to merge with SMAC (another corporation controlled by the defendant and with which the plaintiff became associated after his stock sale ${ }^{67}$ ). As to these alleged misrepresentations, the court held that the plaintiff was experienced enough to appreciate the precarious nature of the housing business. He knew it was impossible to lay concrete plans in developing raw land of this size in the tenuous business circumstances of the mid-1960's. He knew of all the uncertainties involved: that the Ryan Hoines corporate entity might not exist from year to year, or that the Board of Directors might change or obstruct the plans which ... [ [the defendant] envisoned; or that Edward Ryan might become insolvent or fail in health or die. ${ }^{88}$

The decision appears reasonable since it should be generally accepted that many propositions are affirmatively stated even though both declarer and listener realize contingencies could arise to make the affirmative declaration false. The plaintiff in a $10 \mathrm{~b}-5$ suit for misrepresentations should be held responsible for foreseeing obvious comphications which might arise and prevent fulfillment of a defendant's projections.

A different conclusion should be reached, though, where a representation is central to the transaction and where the plaintiff could foresee a statement's possible falsity only by concluding that the defendant had been lying. In such cases, the plaintiff should be allowed to recover. For example, in Burns v. Paddock ${ }^{69}$ certain officers and directors alleged that they had been fraudulently induced to imvest in the company by other directors who were also the majority shareholders. The plaintiffs contended that the defendants had promised the establishment of a voting trust through which the plaintiffs, even though minority shareholders, would control the company. ${ }^{70}$ In fact, no such trust was ever established. The defendants countered that the plaintiffs should not have relied on the promise simce the plaintiffs knew that three out of the five trustees were to be the defendants or those allied with them. ${ }^{71}$ The Seventh Circuit refused to dismiss the

67. 360 F. Supp. at 885 .

68. Id. at 886. The merger never went through because SMAC had been threatened with VA and FHA disqualification. In order to go public, Ryan Homes needed to disassociate itself from SMAC. $I d$. at 883 . This was apparently also the reason why the trade name "Ryan Homes" was not retained in use at the new land development site. Id. at 884 . 1974).

69. [Current Transfer Binder] CCH Fed. Sec. L. Rep. I 94,789 (7th Cir. Sept. 5,

70. Id. at $96,617-18$.

71. Id. at 96,619 . 
action, ${ }^{72}$ finding it reasonable for the plaintiffs to believe that one of the majority trustees would vote with the plaintiffs to ensure minority control of the voting trust. Otherwise, the defendants' promise to give the plaintiffs control would be meaningless. Only by assuming that these assurances were falsely given could the plaintiffs liave concluded that they would not control the corporation. ${ }^{73}$

\section{Outsider Plaintiffs with Business or Investment Experience}

Many cases have defined the due diligence obligation of "sophisticated" outsiders, i.e., investors with greater than average financial experience and understanding. Such plaintiffs, wherever feasible, must try to obtain current financial information relating to the proposed securities transaction. The sophisticated plaintiff will be charged with knowledge of other types of information whenever the plaintiff's particular kind of expertise relates to the alleged deception. In suits involving brokerage house frauds, such as churning, the courts, despite the fiduciary duty between broker and client, lave been liesitant to impose liability, finding that confirmation slips and monthly statements should put the plaintiff with even minimal sophistication on notice of the fraud.

Corporate Financial Information. Before making a purchase or sale the investor with special expertise must at least seek current financial data on the corporation. In fact, as to information equally available to both groups, the due diligence burden of experienced investors may be higher than that of insiders who lack such expertise. On the other hand, it slould be inore difficult to charge sophisticated outsiders with knowledge of corporate records and meetings to which their access will generally be restricted in comparison with even an unsophisticated imsider.

One case illustrating the due diligence burden for experienced investors is Lane v. Midwest Bancshares Corp., ${ }^{74}$ wherein a stock seller sought to recover on notes given by the purchaser while the latter counterclained for $10 \mathrm{~b}-5$ violations. Specifically, the purchaser alleged that certain liabilities had been omitted from the corporate balance sheet that he was shown. Although agreeing that the omission was material, the court noted that both parties were "speculators and shrewd dealers" and that the purchaser was, in fact, a specialist in ac-

72. Id. at 96,623 .

73. Id. at 96,619 .

74. 337 F. Supp. 1200 (E.D. Ark. 1972). 
counting and fimancial management. ${ }^{75}$ Despite his expertise, the counterclaimant bought the stock after only two hours of discussion and without the presence or advice of counsel..$^{76} \mathrm{He}$ had failed to inquire into the fact that the balance sheet was uncertified and over four inonths old. ${ }^{77}$ Thus, the court concluded that the counterclaimant was "either grossly negligent or was recklessly entering into a highly speculative transaction. . ..."78

This, of course, was a face-to-face transaction and the court seened to assume that the counterclaimant could have deinanded and received current certified financial information. If certified financial statements do not exist, an otherwise similarly situated plaintiff should not be demied recovery; only a person making a very large investnent would have the "clout" to demand that certified statements be obtained as a condition to his purchase. Lane should probably be read as inerely requiring the plaintiff investor to demand the best, upto-date financial inforination reasonably available to him. ${ }^{70}$ If that information is maccurate but there is nothing on the face of it to arouse suspicion, the investor should be held to have satisfied his due diligence burden.

Such a reading would correspond with the recent Fifth Circuit case of Vohs v. Dickson, ${ }^{80}$ in which a sophisticated investor was allowed to recover. The plaintiff had purchased stock in Management Science America, Inc., of which she was a project engineer. She specifically alleged that the defendant, a " $k$ ey' employee,"

75. Id. at 1205 .

76. $1 d$.

77. $1 d$. at 1206 .

78. Id. at 1210 .

79. See Kohler v. Kohler Co., 319 F.2d 634 (7th Cir. 1963) (no duty to disclose certain financial information to a plaintiff who had years of intimate acquaintance with the corporation's affairs, had extrinsic sources of such business advice, and was himself promoting a speedy sale).

Cf. Stier v. Sinith, 473 F.2d 1205 (5th Cir. 1973). There the court refused to charge a sophisticated buyer with knowledge that the corporation had made a large loan to another corporation for the express purpose of enabling the latter to buy stock in the former's public offering. The court felt that, although the plaintiff had access to the information, it was hidden in such a mountain of records that the plaintiff could not easily discover it. Id. at 1208.

See also Barthe v. Rizzo, 384 F. Supp. 1063 (S.D.N.Y. 1974). In this suit by an admittedly sophisticated investor, the plaintiff alleged that his broker failed to inform him that he had an interest in the stock he sold to the plaintiff. The court allowed recovery, finding that "one in a fiduciary relationship" is not excused even though the plaintiff-client "was not snfficiently suspicious to think of asking." Id. at 1067.

80. 495 F.2d 607 (5th Cir. 1974).

81. Id. at 623. 
disclose certain material financial data. The court quite willingly pointed out that the plaintiff was a graduate of Duke University and had had some banking experience before coming to MSA; furthermore, she had some $\$ 200,000$ in personal stockholdings and thus was apparently an investor of some experience. ${ }^{82}$ The plaintiff's brother was a graduate of Harvard Business School and the president of a securities brokerage and hedge fund corporation which had dealt with MSA. ${ }^{83}$ Nevertheless, the court found that the plaintiff had satisfied her burden of due care before entering into the transaction since she had obtained a 1968 Annual. Report which she sent to her brother for review, ${ }^{84}$ and had held more than one conversation with the secretary-treasurer of the company "for the purpose of discussing MSA, its stock and fimancial condition." "85 In other words, it was sufficient that the investor had at least made a reasonable effort to gather all currently available financial data.

Even if the securities transaction is an impersonal market transaction, the experienced investor still must seek current financial information from the company. ${ }^{88}$ It is only reasonable to place this due diligence burden on the investor since the corporation cannot be expected to know who is interested in its stock without receiving specific inquiries. ${ }^{87}$

82. Id. at $611-12$.

83. Id. at 612 . One might question whether these facts alone made the plaintiff an experienced investor with a higher burden of investigation. It is unclear whether the plaintiff's stockholdings were merely inherited or were the result of her own efforts. It also seems unfair to mark a plaintiff as sophisticated simply because a member of the plaintiff's family has expertise. However, since the court seeined to treat the plaintiff as a person with extra business sense, she will be so treated in the present discussion.

84. Id. at 614-15. It actually took some effort on the plaintiff's part to obtain the report; her first request was rejected with the claim that the information sought was confidential.

85. Id. at 623. Recovery was denied, however, on the ground that the defendant had no more knowledge or access to the facts than the plaintiff had. But, in a sort of Catch-22, the court also remarked in dictuin that it was reluctant to place any burden on the defendant to have analyzed and explained the footnotes and other financial information in the 1968 Report when the plaintiff herself had, prior to the litigation, taken it upon herself to ascertain the status of the company and its stock. Thus, it seems that an educated and experienced investor is under a duty to carry out an investigation before purchasing or selling securities, but if the investor does make sucl an investigation, then the investor cannot later argue the defendant should have disclosed the information. See A. JACoss, supra note $11, \$ 64.01[\mathrm{~b}][\mathrm{ii}]$ at 3-174.

86. See Shahmoon v. General Dev. Corp., [1973-1974 Transfer Binder] CCH FED. SEC. L. REP. If 94,308 (S.D.N.Y. 1973). The actual holding in Shahmoon is unclear since the court also suggested that no ounission even occurred and, further, that there was no actual reliance on the omission since the plaintiff continued to buy the stock in question even after he actually learned of the allegedly omitted fact.

87. Of course the corporation is still under an obligation not to make misrepresen- 
Other Misrepresentations and Omissions and Fraudulent Devices. Before a sophisticated outsider is charged with knowledge of information other than financial data, it must be found that the plaintiff's experience or sophistication was of a type which would put him on notice of the omitted or misrepresented information or fraudulent scheme. One type of omission that probably all experienced investors can appreciate is illustrated by Maine v. Leonard. ${ }^{88}$ This was a suit by a former executive vice-president and chief engineer who alleged that the purchaser of his stock failed to disclose an impending purchase of the corporate assets by another corporation. The plaintiff sold his stock through a broker, but since the plaintiff was a former insider, ${ }^{30}$ and the stock was unregistered and restricted, he demanded and received a letter of indemnification from the purchaser, whose identity was unknown to him. The letter was kept in the broker's files. A month after the sale, the local newspaper reported the purchase of assets. The plaintiff admitted that after these newspaper reports he had suspected an insider may have been involved in the purchase of his stock. Yet the plaintiff waited nineteen months before writing to the broker to request the name of the purchaser and, after the broker refused, he waited another two years before inaking further inquiries. Finding that the plaintiff possessed the "sophistication and expertise" necessary to appreciate the meaning of these events, ${ }^{90}$ the court concluded that the plaintiff had failed his due diligence burden of investigation and refused to toll the statute of limitations which barred recovery. ${ }^{91}$

tations or misleading statements in the information which it does release. See, e.g., SEC v. Texas Gulf Sulphur Co., 401 F.2d 833 (2d Cir. 1968), cert. denied, 394 U.S. 976 (1969).

88. [1973-74 Transfer Binder] CCH FED. SEC. L. REP. I 94,407 (W.D. Va. 1973).

89. The plaintiff had left the corporation about three months before the stock sale. Id. at 95,411 .

90. $1 d$. at 95,414 .

91. Id. at 95,417 . For another case where the plaintiff's expertise related to the fraud perpetrated and thus barred recovery see Clement A. Evans \& Co. v. McAlpine, 434 F.2d 100, 103-04 (5th Cir. 1970), cert. denied, 402 U.S. 988 (1971). The plaintiff brokerage firm alleged that certain defendants had created the illusion of financial responsibility for another defendant, McAlpine, thereby inducing the plaintiff to permit the latter to trade large volumes of securities. McAlpine purchased securities from the plaintiff with personal checks, which the plaintiff continued to accept even after prior checks had been dishonored for insufficient funds and even though regulations required the plaintiff to freeze the customer's trading account for ninety days. Id. at 101-02.

But see Carroll v. First Nat'1 Bank, 413 F.2d 353 (7th Cir. 1969), cert. denied, 396 U.S. 1003 (1970). Certain "participants" here made large purchases of securities through the plaintiff securities dealers, thereby driving up the price of the securities and allowing the participants to pay for the origmal purchases by unloading the securities at inflated prices. The participants were aided in the creation of this "credit bubble" 
On the other hand, in John R. Lewis, Inc. v. Newman ${ }^{92}$ recovery vas permitted since the plaintiffs' expertise did not relate to the misrepresented information. The plaintiff-buyers in the case were corporations engaged in the securities business and had been investing in the stock in question for over ten years. They alleged that the seller, an investor in close touch with corporate inanagement, misrepresented that he was acting for the corporation and that the unregistered shares he was offering could be later exchanged for registered shares. These misrepresentations, the court found, were such that years of investment experience and past dealings between the plaintiffs and defendant could not put the plaintiffs on notice that the defendant was not telling the truth..$^{93}$ If the plaintiffs had been comrected with the corporation, like the foriner insider in Maine, then the case should have come out differently because the plaintiffs could easily have checked to see if the shares were exchangeable. Even on the facts as stated the decision is questionable. One wonders why the plaintiffs did not even bother to verify the defendant's representations with the corporation itself, particularly since the defendant inade the unusual promise that the shares were exchangeable. ${ }^{94}$

Suits Against Brokerage Firms. Special problems have been presented in the several cases involving allegations either of "churning"95 of the plaintiff's account by a defendant broker-dealer or of unauthorized or undermargined transactions in the account. ${ }^{96}$ These

by the defendant bank which held drafts sent by the plaintiffs as long as possible without paying for the securities. Id. at 355 . The court explicitly discounted the relevance of the plaintiff's negligence in handling sales of securities, id. at 357-58, and refused to dismiss the complaint. The Seventh Circuit has tended to require very hittle for a plaintiff's showing of due diligence. See notes 105-07 infra and accompanying text. The court in Carroll did note however, in a confusing aside, that the plaintiffs' negligence might be somehow relevant to the issues at a trial on the merits. Id. at 358 .

92. 446 F.2d 800 (5th Cir. 1971).

93. Id. at 804 .

94. See also Lehigh Valley Trust Co. v. Central Nat'l Bank, 409 F.2d 989 (5th Cir. 1969) (recovery by plaintiff bank which, although experienced in intricacies of loan participation agreements, was located in small Pennsylvania town and thus "had no way to independently verify the information supplied by [defendant] Central Bank which was on intimate terms with the borrower." Id. at 993.)

95. "Chuming" is defined as the overtrading of an account in order to generate commissions. See 3 L. Loss $1479-80$.

96. See, e.g., Ocrant v. Dean Witter \& Co., 502 F.2d 854 (10th Cir. 1974); McCormick v. Esposito, 500 F.2d 620 (5th Cir. 1974), cert. denied, 95 S. Ct. 834 (1975); Dzenits v. Merrill Lynch, Pierce, Fenner \& Sunith, Inc., 494 F.2d 168 (10th Cir. 1974); Fey v. Walston \& Co., 493 F.2d 1036 (7th Cir. 1974); Landry v. Heinphill, Noyes \& Co., 473 F.2d 365 (1st Cir.), cert. denied, 414 U.S. 1002 (1973); Gammage v. Roberts, Scott \& Co., [Current Transfer Binder] CCH Fed. SEC. L. REP. If 94,760 (S.D. Cal. June 13, 1974); Hecht v. Harris, Upham \& Co., 283 F. Supp. 417 (N.D. Cal. 1968), 
frauds usually take place over a period of time during which the plaintiff is presumably being sent both monthly stateinents and confirmation slips. ${ }^{97}$ If the defendant can slow that the plaintiff was experienced or sophisticated enough to appreciate the facts contained in the statements or confirmations received, recovery inay be denied on the ground that the plaintiff, by his inaction, failed to satisfy his due diligence burden. Thus, the only question is whether the plaintiff was, in fact, sufficiently "experienced" or "sophisticated." In answering this question, the courts have tended to be defendant oriented because of the fact that the monthly statements provide the inforination necessary for discovery of the fraud.

If the plaintiff or, as more typically happens, the plaintiff's agent-liusband is actually engaged in the securities business, it is proper to presume that the plaintiff lias the expertise to understand the statements and recovery will be denied. ${ }^{98}$ If the plaintiff is not a broker or regular speculator, then generally more evidence is required before a court will hold that the plaintiff should have understood the confirmation slips. A review of the cases will show that the judicial approach lias been a reasonable one. The First Circuit has found sufficient evidence where the plaintiff was a high school graduate, was engaged in the insulating, painting and carpentry contracting business, earned between $\$ 15,000-\$ 25,000$, had been trading in the market since the 1950's, subscribed to Barron's and the Wall Street Journal, had solicited investment advice, and liad retained his confirmation slips to prepare a list of current stockholdings, thereby indicating he conuprelended the information on the slips.99 In a suit alleging margin violations, the Fifth Circuit held a plaintiff barred by the due diligence requirement where he was a lawyer and had been investing in the securities nuarket since $1929 .{ }^{100}$ Thus, it can generally

modified, 430 F.2d 1202 (9th Cir. 1970); Nash v. J. Arthur Warner \& Co., 137 F. Supp. 615 (D. Mass. 1955); Carr v. Warner, 137 F. Supp. 611 (D. Mass. 1955).

97. If no confirmation slips and statements are sent, then the plaintiff, of course, has a much better case. However, the defendant might still argue that the plaintiff was sophisticated enough to appreciate the absence of the slips and should have made an inquiry.

98. See, e.g., Ocrant v. Dean Witter \& Co., 502 F.2d 854 (10th Cir. 1974) (churning claim denied where plaintiff's agent-husband was active investor and hicensed broker); Gammage v. Roberts, Scott \& Co., [Current Transfer Binder] CCH FED. SEC. L. REP. I 94,760 (S.D. Cal. June 13, 1974) (in suit alleging margin violations, plaintiff denied recovery where her agent-husband held graduate degree from Harvard Business School and made his living from speculating in the securities market).

99. Landry v. Heinphill, Noyes \& Co., 473 F.2d 365, 373 n.10 (1st Cir.), cert. denied, 414 U.S. 1002 (1973).

100. McCormick v. Esposito, 500 F.2d 620 (5th Cir. 1974), cert. denied, 95 S. Ct. 
be said that recovery will be denied when the plaintiff has been trading in the nrarket for a substantial period of time and his occupation or actions indicate a likely understanding of the monthly statenrents. ${ }^{101}$ However, since the issue of the plaintiff's sophistication is an issue of fact, the Tenth Circuit has allowed a churning case to go to trial even though plaintiff was a dentist and had been investing for some ten years, in view of the additional fact that the plaintiff was a native of Latvia and had come to the United States during World War II. ${ }^{102}$ It was not inade clear, however why the plaintiff's background should have affected his understanding of confirmation ships simce the plaintiff had been in the United States for over twenty years.

If the plaintiff alleges "unauthorized transactions" in an account, less evidence of sophistication should be required since it is easier to tell froin a monthly statement whether trades have been made which the investor did not authorize. Churning, on the other hand, actually requires a coniparison of nonthly statements in order to see how nuany times a stock has been turned over or how many trades have been made during a substantial period of time. In Hecht

834 (1975). It is actually hard to tell in this case whether the plaintiff was denied recovery because he should have known his account was undermargined and failed to take corrective action or because the plaintiff had actual knowledge of the violation. The court simply states:

McCormick received a monthly statement of his account and was aware of the varying equity-debit status of his account. He certainly had reason to know when his account was undermargined, for as the district court found, "Mr. McCormick is a lawyer, has been im and out of the securities market place since 1929, personally maintained full control over his account, and was at all times completely informed as to the securities position of his account." Id. at 628.

For a case denying recovery to a plaintiff with actual knowledge of margin violations see Gordon v. duPont Glore Forgan, Inc., 487 F.2d 1260 (5th Cir. 1973). The court simply found it inequitable to allow a plaintiff who had gambled that his stock would appreciate (so that he would not have to bolster his margin account) to recover because the stocks fell so low that his margin account had a deficit. Id. at 1263. But see Pearlstein v. Scndder \& German, 429 F.2d 1136 (2d Cir. 1970) (recovery for margin violations permitted on ground that "the danger of permitting a windfall to an unscrupulous investor is outweighed by the salutary policing effect which the threat of private suits for compensatory damages can have upon brokers and dealers ...." Id. at 1141).

101. One case has gone even further. In Nash v. J. Arthur Warner \& Co., 137 F. Supp. 615 (D. Mass. 1955), recovery was denied on a churning claim where one plaintiff, albeit with little formal education, was a successful plumbing contractor and had borrowed money froin a bank, pledging secnrities as collateral; the other plaintiff, possessing a sixth grade education, prepared tax returns for himself and relatives and kept daily contact with newspaper reports of the prices of securities. See also Carr v. Warner, 137 F. Supp. 611 (D. Mass. 1955) (recovery denied housewife who was high school graduate with twelve years experience of working at a bank).

102. Dzenits v. Merrill Lynch, Pierce, Feuner \& Smith, Inc., 494 F.2d 168, 170 (10th Cir. 1974). 
v. Harris, Upham \& $C_{0}{ }^{103}$ the Ninth Circuit was willing to estop a relatively inexperienced investor from denying that she knew the nature of the transactions in her account because she had received confirmation slips, but the court was careful to note that she would not be estopped from claiming that her account was traded excessively. ${ }^{104}$

When churning is alleged, the degree of sophistication of the mvestor can be an important factor. ${ }^{105}$ In reversing a district court which would not admit evidence of an investor's sophistication in a churning case, the Seventh Circuit stated in Fey v. Walston \& Co. ${ }^{108}$ that "evidence bearing upon the experience, sophistication or trading naivete of the customer may be highly significant."107

\section{Ordinary Plaintiffs}

Even "ordinary" plaintiffs, who by definition have no special business or investment expertise and are neither officers nor directors, must meet certain minimal standards in order to recover. In applying the due diligence test to unsophisticated investors, courts have properly focused upon the plaintiffs' own unique knowledge and experience, as well as upon their access to the relevant information. Furthermore, it is evident from the recent decisions that a modicum of good judgment will be required from even the most imexperienced investor.

Current Market Price and Book Value. At a minimum, due diligence requires an ordinary investor to ascertain the current market price of the stock, at least where it is readily available to the public in

103. 430 F.2d 1202 (9th Cir. 1970), modifying 283 F. Supp. 417 (N.D. Cal. 1968). The plaintiff, a former housekeeper who had married her former employer, was approximately sixty-five years old when she inherited a half million dollars worth of securities from her husband. $283 \mathrm{~F}$. Supp. at 424 . During the almost seven years that her account was at Harris, Upham \& Co., over 10,000 transactions occurred in it with a gross dollar volume of $\$ 100,000,000$. Nearly ninety percent of these transactions were in commodities. Id. at 425 .

104. 430 F.2d at 1209.

105. Mrs. Hecht relied on the advice of her broker to the extent that he controlled the volume and frequency of transactions. 283 F. Supp. at 431-32. Presumably, a more sophisticated investor would fail in making this argument because such blind reliance on his broker would not be reasonable. Cf. Gammage v. Roberts, Scott \& Co., [Current Transfer Binder] CCH FED. SEC. L. Rep. I 94,760 (S.D. Cal. June 13, 1974). Unlike Mrs. Hecht, Mrs. Gammage was not under the control of her broker nor did she place any great reliance on him. Id. at 96,503. Instead she was advised by her husband-agent who had over 20 years experience in dealing in securities. Id. at 96,500. Therefore, Mrs. Gammage was unsuccessful in claiming that she was unaware of the transactions taking place in her account.

106. 493 F.2d 1036 (7th Cir. 1974).

107. Id. at 1045. 
the National Daily Quotation Sheets. ${ }^{108}$ This requirement typically is imposed when the plaintiff has carelessly sold his stock below market value; a plaintiff may also be charged with knowledge of the current market price when he seeks to overcome the bar of the statute of limitations. For example, in Hupp v. Gray ${ }^{109}$ the plaintiff alleged that he was induced to purchase shares in a variable annuity insurance company by a stockbroker's misrepresentation that the Chicago School Board was about to execute a contract with the insurance company for a group policy covering thousands of teachers and that the market price of the stock would consequently soar. ${ }^{110}$ In reality, after the plaintiff completed his purchases, the market price fell drastically and the plaintiff was eventually forced to sell. ${ }^{111}$ However, the plaintiff waited four more years before filing his complaint. Reasoning that even a wholly unsophisticated imvestor should have realized that he was defrauded when the stock price plunged rather than soared, the court refused to toll the statute of limitations and denied recovery. ${ }^{112}$

Charging ordinary plaintiffs with knowledge of publicly available market prices seems to be a wholly reasonable requirenient, since every investor should have access to a newspaper and no particular expertise is needed to understand the daily quotations. A more difficult question is whether to charge a plaintiff with knowledge of the book value of the stock of a closely held corporation. ${ }^{113}$ If the plaintiff is a seller, the extent of the due diligence burden should depend on his access to the information. ${ }^{114}$ This was the approach taken by the Sixth

108. See Hafner v. Forest Laboratories, Inc., 345 F.2d 167 (2d Cir. 1965).

109. 500 F.2d 993 (7th Cir. 1974).

110. Id. at 995.

111. When the plaintiff completed his purchases the market price was $\$ 47.00$. Although the defendant had predicted the market price would soon rise to $\$ 75.00$, a year later the price was down to $\$ 17.50$. The plaintiff then sold. $I d$.

112. Id. at 997.

113. Shareholders, of course, do not have an absolute right to inspect corporate books and records. Although statutes vary, a shareholder may have the burden of alleging and proving good faith and proper motive for the inspection. See Starr \& Schmidt, Inspection Rights of Corporate Stockholders: Toward a More Effective Statutory Model, 26 U. FLA. L. REv. 173 (1974). Because corporations have so little to lose in resisting a shareholder seeking to enforce his right of inspection, the shareholder often encounters considerable delay before gaining access to the books. See $i d$.

Professor O'Neal suggests that the charter of a close corporation should give its shareholders greater rights of inspection than the shareholders of a public corporation would have by statute or common law. $1 \mathrm{~F}$. O'Neal, Close Corporations $\$ 3.63$ (1971).

114. The courts will not always aid the shareholder in getting this information. See State ex rel. Jones v. Ralston Purina Co., 358 S.W.2d 772 (Mo. 1962) (shareholder's inspection right does not extend to preliminary profit and loss statement, a monthly 
Circuit in Arber v. Essex Wire Corp. ${ }^{115}$ where the court specifically found that the information was easily available and that the plaintiff knew of its availability. No cases appear to have arisen where the plaintiff was buying into a close corporation. However, it would seein equitable to require that the buyer at least have inade a reasonable inquiry into the book value of the stock. If such an inquiry would not have uncovered the inaterial information, recovery should be allowed.

Other Misrepresentations and Omissions and Fraudulent Devices. Beyond knowledge of narket price and (at least in some cases) book value, the ordinary investor will be charged with whatever knowledge reasonable diligence would have gleaned from the facts of each case. Most of the cases have been clear cut. For example, an ordinary investor has been held obliged to discover a curative corporate press release within four days of its issuance. ${ }^{116}$ The investor inay also be under a duty to discover, after a period of time, that a stock purchaser misrepresented the individual on whose behalf he was acting. Such a duty was imposed in Morgan v. Koch, ${ }^{117}$ where the plaintiff, a psychiatrist, sold her stock to the defendant on the condition that the defendant was not associated with the plaintiff's brother, the president of the corporation, with whom the plaintiff was feuding. The defendant falsely represented that he was not comected with the brother and would not retain him in the management structure. Three years after the statute of limitations had run, the plaintiff finally brought suit. The court intimated that the plaintiff should have suspected the truth before the actual sale was made; the evidence indicated that the plaintiff's brother headed a voting trust that was to remain in effect for another nine years, and thus a reasonable seller would lave inferred that the purchase was not being made for the defendant.118 But, snore importantly, the court found that the plaintiff could easily have discov-

profit analysis and detailed balance sheet); Baron v. Royal Paper Corp., 36 App. Div. $2 d 112,318$ N.Y.S.2d 327 (1971) (shareholder in close corporation selling his shares to the corporation pursuant to a buy-out agreement not allowed to examine books to see if they accurately reflected the book value). But see Waldman v. Eldorado Towers, 25 App. Div. 2d 836, 270 N.Y.S.2d 216 (1966).

A shareholder should not be forced to give up a possible sale simply because the corporation is interposing unreasonable delay in allowing the plaintiff to inspect the records to determine book value. This principle would be especially applicable where the defendant buyer was the corporation itself, as well as where the buyer is an insider with knowledge of book value which he does not disclose to the plaintiff.

115. 490 F.2d 414 (6th Cir.), cert. denied, 419 U.S. 830 (1974).

116. See Mitchell v. Texas Gulf Sulphur Co., 446 F.2d 90 (10th Cir. 1971).

117. 419 F.2d 993 (7th Cir. 1969).

118. Id. at 997-98. See also notes 131-34 infra and accompanying text. 
ered that her brother was retained as chief executive after the sale. Newspapers published stories that the brother was to remain in the corporation, and the plaintiff frequently visited relatives who lived near the corporation's headquarters. ${ }^{119}$ Because of the extremely strong evidence of constructive knowledge, the plaintiff's suit was barred by the statute of limitations.

In addition, even unsophisticated plaintiffs may be charged with knowledge of elementary technical matters which they had ample opportunity to discover. For example, an ordinary investor has been placed under a duty to discover the redemption procedure applicable to his convertible bonds, at least where sufficient information is given in the prospectus and on the bonds themselves. ${ }^{120}$ A plaintiff cannot simply deposit the bonds in his safe deposit box without reading them and then be heard to complain when the bonds are redeemed before he has a chance to convert. On the other hand, an ordinary investor has no duty to find out nore esoteric information, such as the fact that unregistered stock held by other investors might be sold under SEC Rule 144 and that such sales could negatively affect the market price of common stock purchased by the plaintiff. ${ }^{121}$ Such knowledge would require inore than a passing acquaintance with the securities laws, while every investor in convertible bonds should realize he inust familiarize himself with the redemption procedure.

All of these cases seem relatively straightforward. Other cases have arisen, however, where proper resolution of the due diligence issue has presented greater difficulty. In Bird $\nu$. Ferry, ${ }^{122}$ for example, a securities salesman who had served as an investment adviser for the "Twenty-Ten Investment Club" managed to abscond with all of the club's funds. He accomphished this by placing the club's portfolio in his own personal account and furnishing bogus statements to the club tracing the vicissitudes of their non-existent stocks. ${ }^{123}$ Although the club nienibers included "a lawyer, a doctor, a bank teller, two real es-

119. Id. at 998. For another case holding that the plaintiff investor failed to exercise due diligence see Branhain v. Material Systems Corp., 354 F. Supp. 1048 (S.D. Fla. 1973); cf. Baumel v. Rosen, 412 F.2d 571 (4th Cir. 1969) (plaintiffs demied remedy of rescission where they waited alinost three years after the time plaintiff-sellers admitted they realized they had been "taken" before bringing suit).

120. See Abramson v. Burroughs Corp., [1971-72 Transfer Binder] CCH FED. SEC. L. REP. I 93,456 (S.D.N.Y. 1972).

121. See Langert v. Q-1 Corp., [1973-74 Transfer Binder] CCH Fed. Sec. L. REP. II 94,445 (S.D.N.Y. 1974). For other cases where ordinary investors have satisfied their due diligence burden see deHaas v. Einpire Petroleum Co., 435 F.2d 1223 (10th Cir. 1970); Royal Air Properties, Inc. v. Smith, 333 F.2d 568 (9th Cir. 1964).

122. 497 F.2d 112 (5th Cir. 1974).

123. Id, at 113-14. 
tate brokers, two pharmacists, and the president of a corporation,"124 the club carelessly let the stocks fall into the defendant Ferry's hands when Ferry changed employers. Instead of instructing the former employer to transfer the club's stock directly to the new employer to be held in a street name, the club treasurer merely requested a transfer to Ferry himself, albeit with the presumption that Ferry would ultimately transfer the stocks on his own. ${ }^{125}$ No club member, however, ever asked for a confirmation of the transfer or a broker's receipt for the stock. ${ }^{126}$ Perhaps even more negligently, the club members never requested confirmations of any authorized purchases and sales, although the club treasurer testified that he knew what confirmation slips were. ${ }^{127}$ In addition, there was evidence that Ferry had mishandled $\$ 5,000$ in funds belonging to one club member who "felt Ferry stole his money and may have told other members of his suspicions." 128 Despite all these acts of gross negligence, the majority concluded that recovery was justified by Ferry's "quasi-fiduciary position." 129 But, in view of the professional occupations of the plaintiffs, it is difficult to justify such blind reliance. ${ }^{130}$

Common Sense. As in the case of insiders ${ }^{131}$ and sophisticated investors, ${ }^{132}$ the ordimary imvestor's due diligence burden goes beyond making a reasonable inquiry; he must also apply his common sense to the facts that are given to him. This principle is most important where the plaintiff alleges that he was misled by extravagant claims. While the ordinary investor need not exhibit sophisticated business sense, he should realize that predictions of extraordinary profits are, at least in certain industries, to be skeptically received. For example, in Ferland v. Orange Groves of Florida, Inc. ${ }^{133}$ the plaintiff alleged that hitera-

124. Id. at 114 (dissenting opinion of Judge Coleman).

125. Id. at 115 (dissenting opinion of Judge Coleman).

126. $I d$.

127. Id. at 116 (dissenting opmion of Judge Coleman).

128. Id. at 114 .

129. Id.

130. Judge Coleman wrote a vehement dissent in Bird finding a complete lack of diligence on the plaintiffs' part. Id. at 114-20. However, even Judge Coleman considered the lack of diligence to be no defense as to Ferry's liability, but only as to the liability of Robinson-Humplurey under the controlling persons provision of the securities laws. 15 U.S.C. $\$ 78 \mathrm{t}$ (1970). Nor would Judge Coleman have allowed plaintiffs' carelessness to be raised on the common law counts of fraud and respondeat superior against Robinson-Humphrey.

131. See notes 67-71 supra and accompanying text.

132. Actually, no cases appear to have arisen involving the duty of sophisticated plaintiff investors to apply their common sense in interpreting information supplied to them in a securities transaction. Undoubtedly, however, placing such a burden on sophisticated investors would be reasonable.

133. 377 F. Supp. 690 (M.D. Fla. 1974). 
ture used in the sale of oringe grove interests portrayed an "over-roseate" view of the citrus industry. The court, however, declined to interpret the language as a guarantee of future profits, reasoning that, because of the nature of the investment and its dependence on weather and other risks of nature, "an average prudent investor would recognize any guarantee of profits as a manifest impossibility."134 In a declining econoiny, this principle might well be extended to almost every industry, with the result that plaintiffs should find it increasingly inore difficult to base $10 \mathrm{~b}-5$ suits upon allegations that handsome returns on their investment were guaranteed.

\section{CONCLUSION}

It is becoming increasingly rare for courts to allow recovery under rule $10 \mathrm{~b}-5$ without scrutinizing the plaintiff's conduct as well as that of the defendant. The principle that only those investors who have acted reasonably should prevail in 10b-5 suits is now firmly established. This Note has attempted to show that the imposition of such a due diligence requirement upon plaintiffs is an appropriate way of defining a judicially created remedy in accordance with legislative policy. Of course, any test which requires "reasonable" conduct has ineaning only in light of the specific circumstances of individual cases. However, $10 \mathrm{~b}-5$ cases generally show a predictable regularity both as to the types of planitiffs and as to the nature of their alleged negligence. In recognition of this fact, this Note has presented the due diligence test in terms of the conduct which should be required from ineinbers of the most frequently encountered classes of plaintiffs. The general standards of conduct for investors have already taken shape; those who fail to conform their conduct to these standards will almost certainly forfeit the protection of rule $10 \mathrm{~b}-5$.

134. Id. at 705. See also Ply-Gem Indus., Inc. v. Green, [Current Transfer Binder] CCH FED. SEC. L. REP. IT 94,705 (2d Cir. July 9, 1974) (plaintiff investor was given sufficient disclosnre of two unfavorable government contracts held by corporation); Phillips v. Reynolds \& Co., 294 F. Supp. 1249 (E.D. Pa. 1969) (plaintiff investors who failed to carefully read Time magazine article given them by broker which stated "more than $\$ 12$ million has been poured into" corporation without a cent of profit cannot recover against broker for inaterial omission).

Cf. Thomas v. Dnralite Co., 336 F. Supp. 698 (D.N.J. 1974). The plaintiff here was a former insider and might be deemed an experienced investor. The plaintiff alleged he was not told of an impending lucrative merger, although he admitted the defendant said that he himself was holding on to his own shares because "someone" might want to buy the company. The court found for the plaintiff on the gronnd that "in the context of the conversation," the defendant's reference to the fact that the company might be worth "something" to "somebody" "conveyed the flavor of a garage sale, not that of an important inerger." Id. at 717. 